\title{
FROM SPICES TO OIL: SEA POWER AND THE SEA ROUTES AROUND THE CAPE
}

Lt C.M. Meyer*

\begin{abstract}
"He who is master of the sea is master of world trade. And he who is master of world trade is master of the riches of the earth and of the earth itself"..")
\end{abstract}

Sir Walter Raleigh, quoted by the former Commander-in-Chief of the Soviet Navy, Admiral S.G. Gorshkov.

\section{Introduction}

Sir Walter Raleigh, the famous English adventurer, died three hundred and seventy years ago, but his words are just as valid today, as any television news programme on convoy operations in the Persian Gulf will show. Warships from the USA, UK, France, Belgium, Italy and the Netherlands have all been involved in patrols or minesweeping operations in the area ${ }^{2}$ to minimize threats to their oil supplies coming from the Gulf, the main export route of nine Middle Eastern countries possessing more than half of the world's proven oil reserves. ${ }^{3)}$

The Straits of Hormuz, conquered by Portuguese forces in 1507 as part of their campaign to establish their monopoly over trade with Indian Ocean states, ${ }^{4}$ ) are now threatened by Iranian forces and Chinese made "Silkworm" missiles. ${ }^{5)}$

Many a Western naval captain now engaged in frustrating and dangerous convoy duties in the Gulf must long for the freedom of action of the early Portuguese leaders who crushed Arab opposition to their presence in that part of the world nearly five centuries ago: Vasco da Gama, who seized Calicut in 1502; Francisco de Almeida, who destroyed the Muslim fleet in 1509; and Afonso de Albuquerque, a strategic genius, who conquered Hormuz in 1507 and then went on to establish Portuguese rule over the Indian Ocean. ${ }^{6)}$

Indeed, four of the nations whose ships are involved in operations in the Persian Gulf, viz, the USA, UK, France and the Netherlands, have dominated the Indian Ocean at different periods in history. The Portuguese were gradually ousted by the Dutch, who were in turn replaced by Great Britain as the major maritime power. While France briefly and successfully challenged British supremacy in the Indian Ocean in the 1780's for control of the sea routes to the
East, ${ }^{7)}$ France's eventual defeat by Admiral Nelson at Trafalgar in 1805 finally dashed her hopes of becoming a global naval power. ${ }^{8}$ Britain maintained her dominant position as a maritime power until the Second World War, whereafter the USA emerged as the leading naval power. ${ }^{9}$ Britain retained, however, a naval presence in the Indian Ocean until 1964, when it was decided to withdraw naval forces east of Suez. ${ }^{10)}$ This decision was motivated at least in part by the humiliating forced withdrawal of British and French forces from the Suez Canal in 1956, where they had been attempting to regain control of it from Egypt. ${ }^{11)}$

This article attempts to highlight the link between the ability to dominate the sea routes from Europe to the East that pass round the Cape, enjoyed by Portugal, the Netherlands and Great Britain at different periods in history, and the economic power enjoyed as a result of this. As the importance of the sea routes round the Cape is linked to the volume of oil being carried on this route by supertankers, it has been deemed necessary to touch on a source of much of this oil, the Persian Gulf and some issues and theories relating to the area, such as the current "oil glut" and low oil prices.

Soviet naval power, and more particularly possible changes in the Soviet naval posture caused by Mr Gorbachev's restructuring of the USSR's armed forces as part of his policy of perestroika, are also touched on. ${ }^{12)}{ }^{13)}$ 14)

To cover this subject matter, the article has been structured as follows:

1. Portuguese sea power: from Bartholomew Dias till the death of Dom Sebastiao.

2. From carriers to colonizers: the rise of Dutch Sea power.

3. The Honourable East India Company, British sea power and the Cape. 


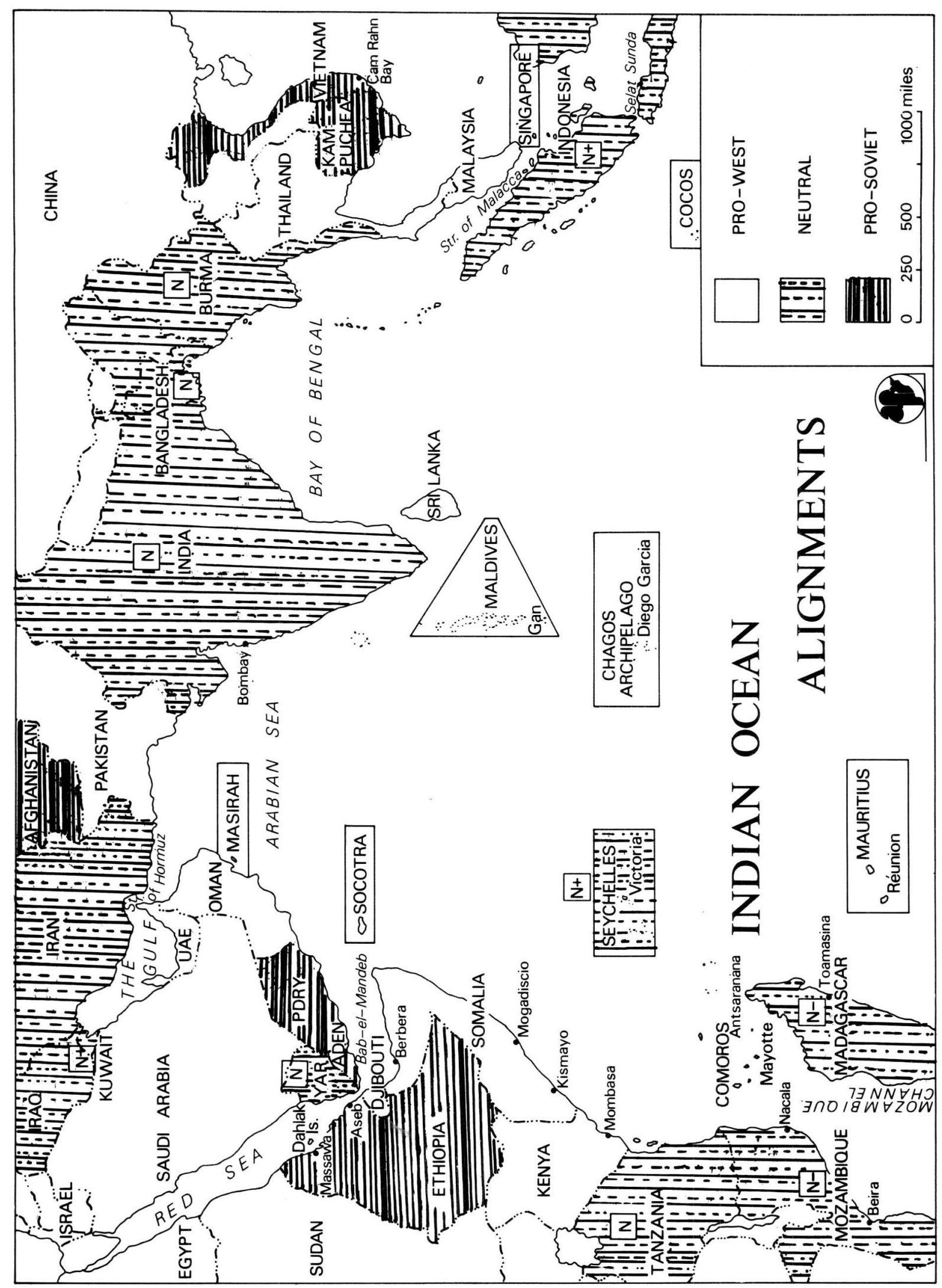

Reproduced with permission from the Africa Institute Bulletin, Vol 25 No's 9 and 10 1985, pp 107 
4. The twentieth century: sea power and the Soviet state.

5. Oil, the Gulf and the Cape.

6. Conclusion: who controls the sea routes around the Cape?

\section{Portuguese sea power: from Bartholomew Dias till the death of Dom Sebastiao}

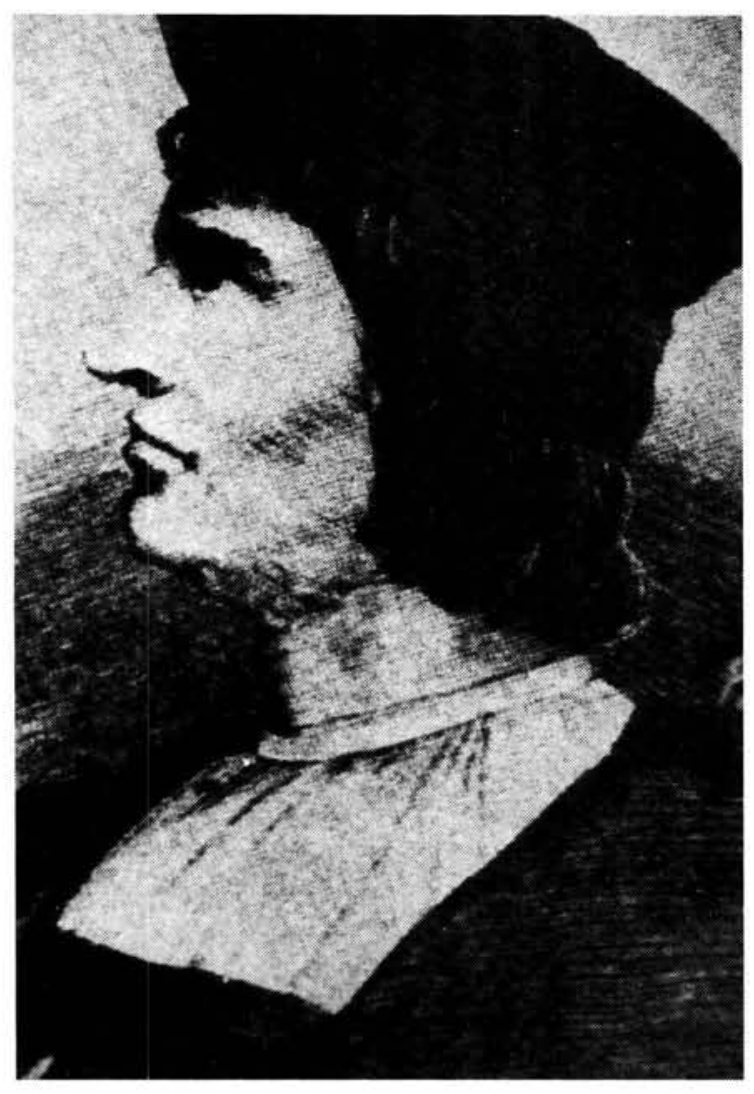

Bartholomew Dias the first European to round the Cape of Good Hope, made his first landing on the South African coastline in 1488

When Bartholomew Dias delivered the epochmaking report of his voyage around the Cape to King John II of Portugal in 1488, one of the persons present was Christopher Columbus. Dias's triumph now dashed Columbus's hopes of obtaining Portuguese funding to sail westwards in search of the Indies. It was thus with Spanish backing that he eventually reached the Bahamas Islands in 1492, mistakenly thinking he had landed in the long sought East Indies. This discovery nearly caused a war between Spain and Portugal, as both claimed Columbus's "Indies" for themselves. ${ }^{15)}$

In a momentous decision, the Pope divided the known world between Spain and Portugal in the
Treaty of Tordesillas, granting King Ferdinand of Castille title to all newly discovered lands west of a line 370 leagues west of the Cape Verde Islands. All new lands east of this line were to belong to Portugal. ${ }^{16)}{ }^{17}$ )

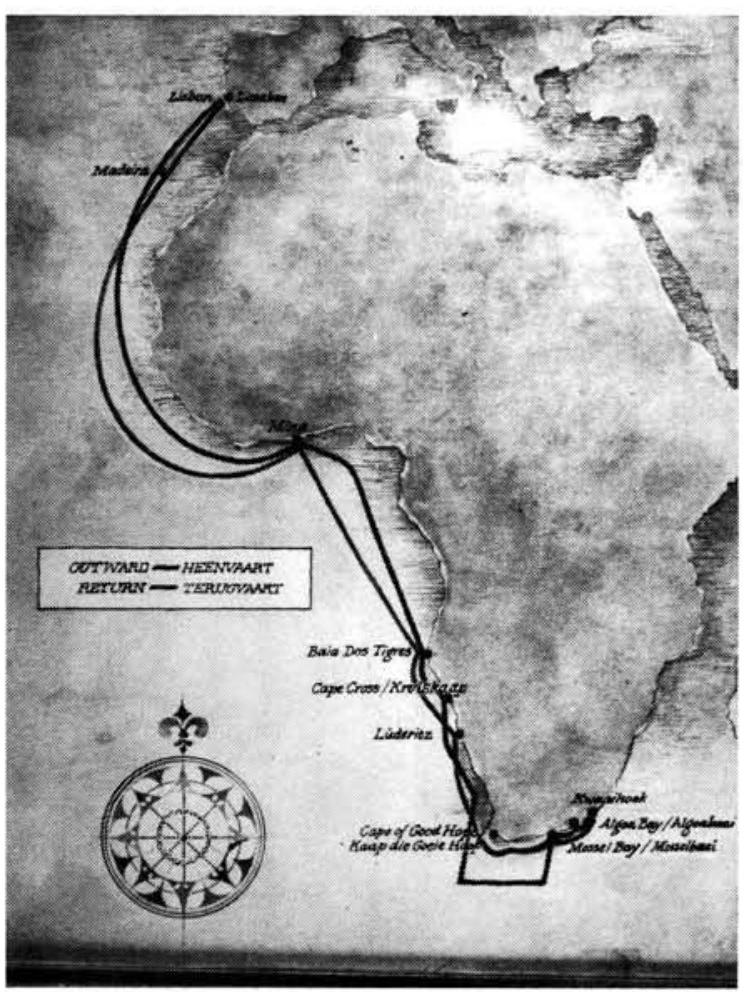

Dias' route round the tip of Africa up to Kwaaihoek where he planted his first padrao (cross) on South African soil

Thereafter, Portugal concentrated on developing and maintaining a monopoly of trade with the East Indies, a monopoly which lasted for nearly a century, ${ }^{18)}$ while Spain turned to creating colonies in the Americas.

It appears that Dias was never properly rewarded by King John II for his momentous discovery. ${ }^{19)}$ While he was given the task of supervizing the building of the ships that were to take Vasco da Gama to India, Dias only accompanied da Gama for part of the voyage, leaving him to go to Sao Jorge da Mina (El Mina ${ }^{20)}$ the Portuguese fortress on the West African coast. ${ }^{21)}$ However, two of the men who sailed on the Sao Gabriel with da Gama had sailed with Dias before: his former pilot, Pedro D'Alenquer (now da Gama's pilot), and Diogo Dias, his brother and, reportedly, captain of his storeship (now da Gama's clerk). ${ }^{22)}$

Vasco da Gama returned to Lisbon in triumph in mid-September 1499 after discovering the sea route to India around the Cape, a triumph some- 
what muted by nearly two thirds of the original crews having died on the voyage from scurvy and other causes ${ }^{23)}$ In February 1502 he set out again for Calicut in India, this time to establish a Portuguese trade monopoly by the use of sea power: a squadron of warships accompanied him. As earlier attempts to negotiate trade agreements had met with obstruction and opposition, force was to be used from now on: any local ruler or Arab shipping opposing Portuguese trade was to be crushed.

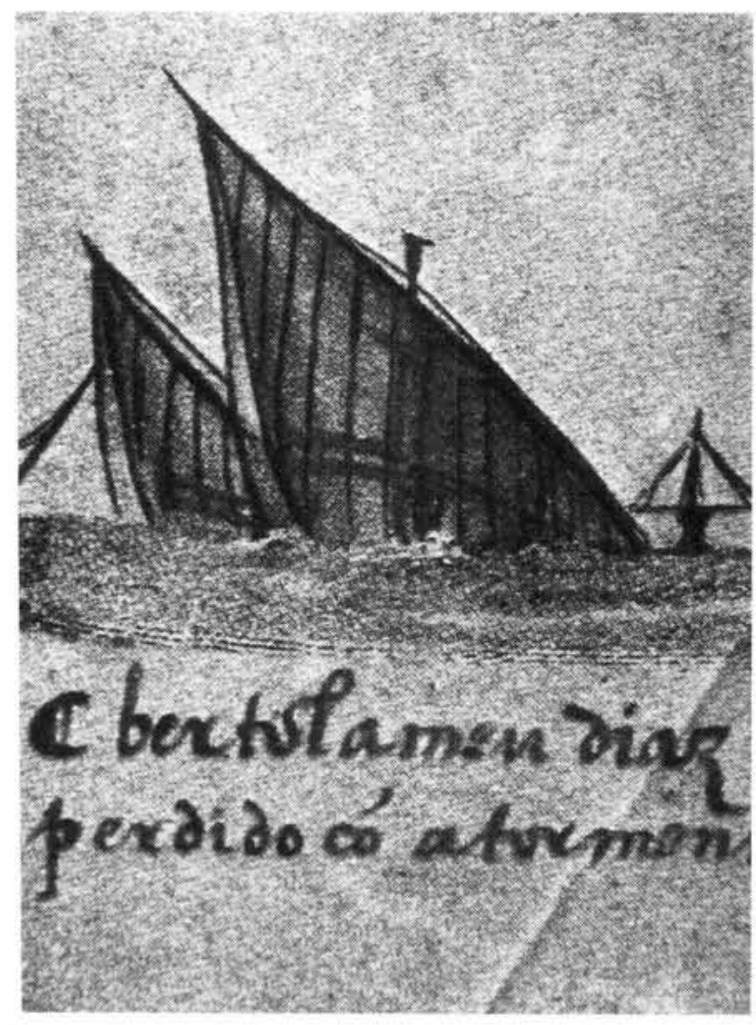

The caravel in which Dias was drowned in 1500, shown sinking after a hurricane. Dias sailed from Lisbon in August 1487 to find a sea passage to India. He was in command of three caravels

In those days, sea trade was little more than legitimized piracy, ${ }^{24)}$ as one of da Gama's crew records:

"We took a Mecca ship on board of which were 380 men and many women and children, and we took from it fully 12000 ducats, and goods worth at least another 10000 . And we burned the ship and all the people on board with gunpowder, on the first day of October". ${ }^{25)}$

On da Gama's return to Calicut, he demanded the ruling Samuri's surrender and the expulsion of all Muslims from the city. When the ruler tried to play for time, da Gama "seized a number of traders and fishermen whom he picked up casually in the harbour. He hanged them at once, then cut up their bodies, and tossed hands, feet, and heads into a boat, which he sent ashore with a message in Arabic suggesting that the Samuri use these pieces of his people to make himself a curry". 26)

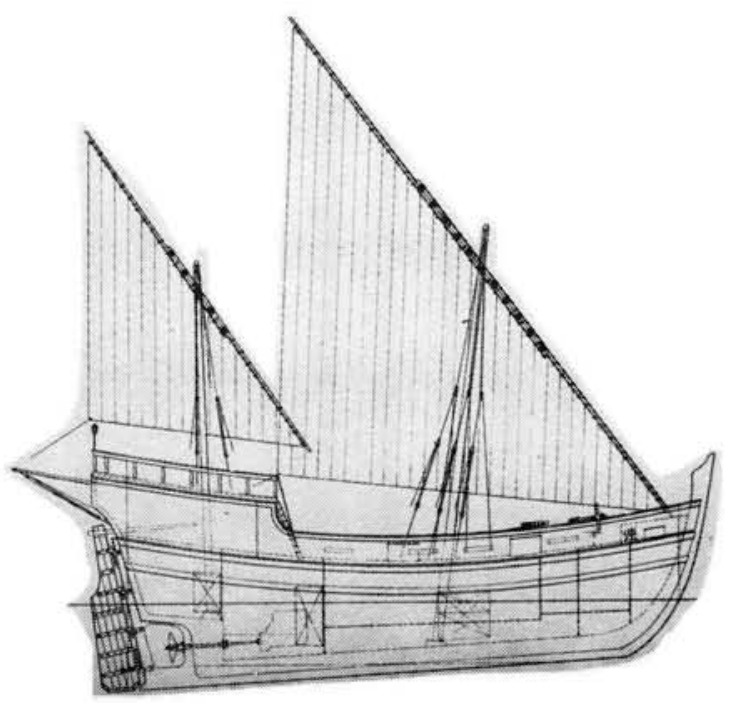

\section{Caravel similar to that of Dias, rebuilt for the Dias Festival}

In Calicut and elsewhere the superior sea power of the Portuguese won the day. Gradually control was gained of a chain of ports on the East African coast - Sofala, Mozambique, Kilwa, Mombasa and Malindi. ${ }^{27)}$ 28)

Unable to defend their trade monopoly effectively against the Portuguese, the Signoria of Venice and the Mameluke rulers of Egypt saw their source of prosperity destroyed. In 1503, the price of pepper in Lisbon had already fallen to one fifth of the price of the same commodity in Venice. ${ }^{29)}$

The Portuguese consolidated their hold on the trade route by ensuring they were the dominant naval power in the Indian Ocean. In this, they achieved spectacular success: Francisco de Almeida, first Portuguese viceroy of India, as noted above, destroyed the Muslim fleet in 1509, and his successor. Afonso de Albuquerque, was an outstanding strategic planner. Within only six years, he had conquered Hormuz (1507), established Goa as the capital of Portuguese possessions in India (1510), taken Malacca (1511), and opened a sea trade with Siam, the Moluccas (Spice.Islands) and China, ${ }^{30)}$ before dying in battle in $1515 .{ }^{31)}$ Portugal now con- 
trolled the Indian Ocean and the lucrative trade route that went with it for most of the sixteenth century. ${ }^{32)}$

A new era has been inaugurated, and the actions of the Portuguese in the 16th century still have implications today. Vasco da Gama's voyage showed that, to be a dominant economic power, a nation also had to be a dominant naval power ${ }^{33)}$ It is surely no coincidence that the USA, at present the dominant economic world power, now has the world's most powerful navy.

The Portuguese rule of the seas was overtaken by events. In 1578, Dom (King) Sebastiao, obsessed with the idea of a great crusade against Islam, launched a disastrous expedition against the Moors in Morocco, in which he and many of the Portuguese nobility that accompanied him lost their lives. ${ }^{34)}$ Phillip II of Spain seized this opportunity to annexe Portugal in $1580,{ }^{35}$ (36) a step that was to prove disastrous for Portuguese control of the seas.

\section{From carriers to colonizers: the rise of Dutch sea power}

The Spanish annexation of Portugal in 1580 set in motion a train of events that resulted in the Netherlands eventually becoming a world class naval power. England, then a small nation with only the beginnings of a navy, ${ }^{37}$ was sufficiently alarmed at the threat posed by Spain to intensify its shipbuilding programme. Dutch and English vessels now began to systematically attack Spanish (and now also Portuguese) ships carrying silver from the new World and spices from the East. ${ }^{38)}$

Because it was not a state sharing land borders with numerous unfriendly states, as was the case with most of Europe at that time, England was not compelled to spend large sums on a standing army and could thus afford to create a powerful navy. ${ }^{39)}$

Although Spain had gained enormous wealth from her American colonies, not enough money had been spent on building up her navy.40) 41) Thus, after the defeat of the "invincible Armada" by the English in 1588, Spain (and, by implication also Portuguese) naval power went into a long decline, lessening her hold on her European provinces and overseas possessions. The United Provinces, the present day Netherlands, had already declared their independence from Spain in $1581 .{ }^{42)}$ Dutch ships had formerly acted as distributors for the Portuguese, carrying goods obtained by the Portuguese trade monopoly throughout Europe. ${ }^{43}$ ) With Iberian naval power in tatters, the Dutch now set out to gain control of the profitable trade monopoly at its source - the East Indies. After initial attempts to wrest control of northerly Portuguese possessions in the Indian Ocean failed, the Dutch decided to outflank the Portuguese by seizing Djakarta in Indonesia in 1618 and making this their centre of operations. ${ }^{44)}$

This had important consequences. As long as the Portuguese had followed the age-old Monsoon route to India and then sailed further to their other possessions, they had no need to land at the Cape of Good Hope - their ships stopped at St Helena and then at Mozambique or other East African ports before catching the seasonal Monsoon winds to India. ${ }^{45)}$ However, the Dutch now pioneered a new direct route to Java, and the Cape was the only stopping place available to them throughout the year. ${ }^{46)}$

The Cape thus became increasingly important as a stopping place for Dutch ships to take on fresh food and water. With the rise of the Dutch East India Company, the need for a refreshment station became so acute that a fort was established at the Cape in 1652. ${ }^{47}$

Interestingly enough, the Netherlands and England were not the only nations to found companies for trading with the East Indies. France and Denmark also founded East India companies, in 1642 and 1616 respectively. However, the superior naval power of Holland and Britain insured, in the long term, that these other companies failed to achieve the marked commercial success of either the British Honourable East India Company (founded in 1600) or the Dutch East India Company (founded in 1602). ${ }^{48)}$ 49)

The Netherlands managed to retain its position as the leading maritime power of the world until after 1780 . Britain was then embroiled in a losing war against its North American colonies, and requested Dutch support. When this was refused, war was declared and the sea power of the Netherlands eventually defeated. ${ }^{50)}{ }^{51)}$

This was the death knell for the Dutch East India Company, already in a state of near bankruptcy, and Dutch control of the Cape of Good Hope. However, this period also left Britain unable to project her power at sea effectively. An earlier indifference to the strategic value of the Cape 
nearly resulted in Britain losing her trade links with the East, as events described below show.

\section{The Honourable East India Company, British sea power and the Cape}

While the Directors of the Dutch East India Company had forcibly expressed the opinion in 1781 that the security of India was determined by the power controlling the Cape ${ }^{52}$ the British learned this the hard way: as a result of French forces controlling the Cape from $1781-1784,{ }^{53)}$ the British possessions in India were nearly lost. ${ }^{54)}$

The situation in India then caused grave concern. A Spanish squadron had taken over the British merchant fleet that traded with India and French forces threatened British control of the Indian subcontinent. At this critical time a British expedition under Admiral Johnstone was despatched to seize control of the Cape.

However, the French admiral Suffren arrived first and put the Cape into a state of defence, forcing Johnstone to return without accomplishing his mission. ${ }^{55)}$ The French were then able to convey substantial reinforcements to their bases in India, and the British forces in India only just managed to avoid defeat. ${ }^{56)}$

As a result of this humiliating experience, the British were thereafter far quicker to react to French naval threats posed by the Napoleonic wars, occupying the Cape twice within eleven years, the second time permanently. ${ }^{57)}$ It may well be that the memory of the near defeat of the British in India as a consequence of them losing control of the sea routes around the Cape was one factor in creating the Simonstown naval base and the now lapsed Simonstown agreement.

Britain was not the only nation where bitter experience in combatting a threat to its interests in the East may have played a part in establishing a naval presence in Africa.

The utter catastrophe which befell the Russian Navy in the Russo-Japanese War of 1904-1905 was analyzed in considerable detail by Admiral Gorshkov, former Commander-in-Chief of the Soviet Navy ${ }^{58}$ ) It is common knowledge that Admiral Gorshkov was also largely responsible for the buildup of the Red Navy into the formidable fighting force it is today - and the acquisition of extensive naval facilities in Africa: Conakry (Guinea), Luanda (Angola), Maputo and Nacala (Mo- zambique), as well as Socotra and Perim Islands (belonging to South Yemen), and Massawa and Assab (Ethiopia) ${ }^{59)}$

\section{The twentieth century: sea power and the Soviet state}

In his seminal book "The Sea Power of the State", Admiral Gorshkov, the man whose navy helped ensure the speedy shipborne supply of troops and equipment that led to the establishment of the MPLA government in Angola in 1975-76, identifies one of the most important factors underlying the catastrophic defeat of the Russian navy at the hands of the Japanese in 1904-1905: an inability to transfer warships from their base (in the Baltic) to the theatre of operations (the Pacific) quickly enough. ${ }^{60}$ )

By the time the dithering and incompetent Russian High Command had authorized the second Pacific squadron under Rozhestvensky to move from the Baltic to the Pacific, it was too late. In the seven months it took the Russian squadron to arrive, Port Arthur fell and the Japanese conducted lengthy preparations to crush what was left of the Tsar's navy. ${ }^{61)}$

\section{As Gorshkov notes concerning Rozhestvensky's doomed voyage:}

"Over the entire route the squadron did not have a single base of its own for resting the crew, for repair and supply. Most of the shores along which it passed belonged to hostile England". ${ }^{62)}$

Today, the situation has changed radically. The Soviet Navy, learning from mistakes made during the Russo-Japanese War (1904-1905), the First World War, the Second World War and the Cuban missile crisis of $1962,{ }^{63)}$ engaged in a massive naval buildup. Now, ironically any Western naval task force following Rozhestvensky's original route to the Far East would indeed find precious few of the shores it passed friendly.

While the geographical separation of Soviet naval bases does still make for problems in concentrating naval forces rapidly, ${ }^{64)}$ there is no doubt that the overseas bases and naval facilities acquired by the Soviet Navy now place it in a vastly improved strategic position, compared to that of the Russo-Japanese war. ${ }^{65}$ )

However, Admiral Gorshkov is no longer Commander-in-Chief of the Soviet Navy. He was re- 
tired in $1985^{66)}$ and replaced by Admiral Vladimir Chernavin, a submarine expert. ${ }^{67)}$ This was just one of the spate of changes in the Soviet High Command ordered by Mikhail Gorbachev as part of his campaign to restructure the Soviet Armed Forces. ${ }^{68)}$ 69) 70) 71) 72) 73) 74)

While it is difficult to predict how these changes may affect Soviet naval strategy, some general observations can be made.

Firstly, Gorbachev seems to doubt the wisdom of allowing the Soviet High Command to continue spending massive sums on grandiose schemes not really essential to the defence of the USSR, such as Gorshkov's expansion programme for the navy. ${ }^{\left.{ }^{75}\right)}$ Gorbachev's first priority would appear to be restructuring and revitalizing the Soviet economy $\left.{ }^{76}\right)^{77)}{ }^{78}$ ) (an economy which appears to have been badly affected by the fall in oil prices ${ }^{79)}$ - this is discussed in more detail in the section below, Oil, the Gulf and the Cape") To achieve this, he must have tighter control over the spending habits of his generals. ${ }^{80}$ ) The reorganization of the Soviet Armed Forces, initiated in $1986^{81)}$ may be seen as a means of improving efficiency by making the Army, Navy, Air Force, Air Defence Forces and Strategic Rocket Forces now function merely as different components of one "all-arms" structure under the supreme control of Marshall N V Ogarkov, who is effectively "deputy commander in chief" directly under Gorbachev. ${ }^{82}$

However, the same reorganization may also make possible tighter financial and political control of the military: unnecessary duplication of projects and facilities would be avoided and any new military projects would now be subject to closer scrutiny from other service chiefs.

Indeed, another possible aspect to the reorganization emerges. While at least three of the recently appointed members of the Soviet High Command, namely Army Gen Y.F. Ivanovsky (Cin-C of Ground Forces), Army Gen Y.P. Maksimov (C-in-C of the Strategic Rocket Forces) ${ }^{83}$ and Admiral of the Fleet V.N. Chernavin (C-in-C of the Navy) ${ }^{84)}$ have expressed support for the integration of their forces into the new all-arms concept advocated by Gorbachev and Ogarkov ${ }^{85}$ ) both members of the High Command apparently dismissed after Mathias Rust's Cessna landed in Red Square, (Defence Minister Sokolov and Air Defence Forces Chief A Koldunov) were known to be uneasy with Gorbachev's restructuring policies. ${ }^{86)}$
Chernavin's appointment, may have implications for Soviet Foreign policy. If the Soviet Navy is no longer going to expand its fleet and build enough aircraft carriers to challenge American control of the seas, this might just signal the beginnings of a foreign policy less heavily based on military capabilities ${ }^{87) ~ 88)}$

On the other hand, the Soviet Armed Forces may be more ready to engage in smaller, more limited wars, as Ogarkov's new doctrine also makes provision for "all-level warfare" without the use of nuclear weapons. ${ }^{89)}$

Be this as it may, it is interesting to note a recent speech by Mikhail Gorbachev, in which he is quoted as saying that the nature of capitalism has changed and its aggressive tendencies have receded, and that the "international conditions under which we have started a new, major phase of one revolution differ essentially from those that existed during its previous stages". ${ }^{90)}$

The possible impact of all this rhetoric on Soviet Naval strategy in unclear. But it is advisable to remember that Soviet leaders, and members of the High Command, do not always stick to what they say when first appointed. Admiral Gorshkov was originally appointed by Khruschev in 1956, because he then enthusiastically supported Khruschev's opinion that Russia needed submarines, not a large, ocean going navy. With the replacement of Khruschev by Brezhnev, Gorshkov then began creating the largest ocean going navy ever possessed by the USSR. ${ }^{91)}$

\section{Oil, the Gulf and the Cape}

Some of the most important cargoes passing the sea routes around the Cape include oil, bauxite ${ }^{92)}$ and chrome ore. ${ }^{93)}$ Metal ores are beyond the scope of this section. Instead it has been deemed necessary to concentrate on oil carried on the sea routes around the Cape, specifically, oil originating from the Persian Gulf.

This is in itself a complex subject, subjected by many factors, ranging from the State of Western economies, the price of oil, their oil purchases from non-Gulf states and the Soviet Union, and the Iran-Iraq war. Because of the mass of conflicting data that can be obtained on each of these topics, only a most cursory analysis can be attempted.

Between the end of the Second World War and 1973, much of the Western World enjoyed a 


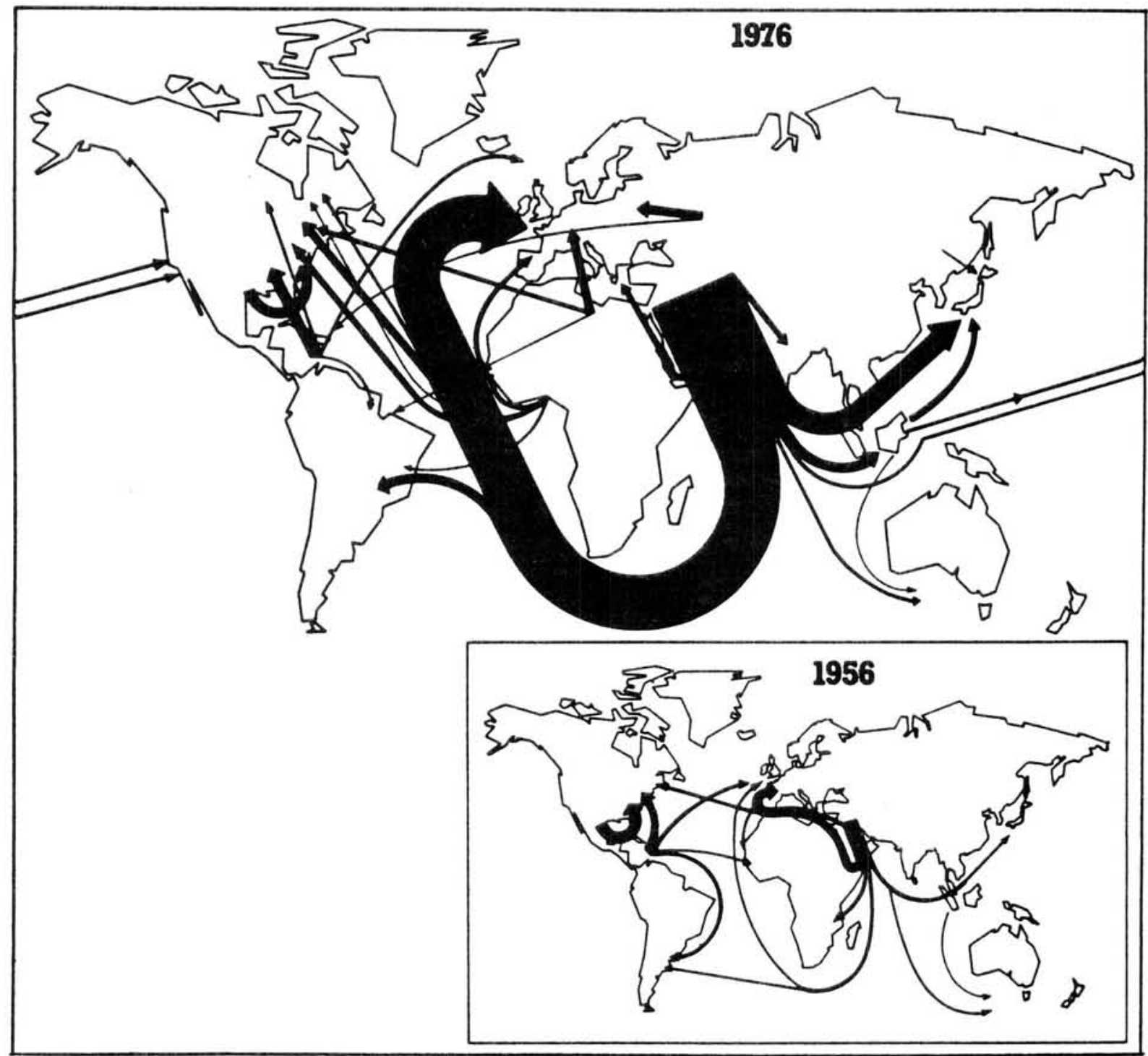

The two maps which illustrate the scale according to which the volume of oil movements by sea has changed over the past 20 years, clearly show how important the Cape Sea Route has become in this period.

(Reproduced with permission from the South African Journal of Science, vol 73, August 1977, p 228.)

period of sustained economic growth that was largely fuelled by cheap oil supplies, much of which came from the Persian Gulf States. ${ }^{94)}$ However, after the Yom Kippur War of 1973, oil prices skyrocketed because of actions by Arab states in OPEC, the cartel of oil producing nations. The price of a barrel of oil, which had risen from about $\$ 1,45$ to $\$ 1,80$ over 25 years, had shot up to $\$ 11,65$ by December $1973,{ }^{95}$ ) helping to plunge many Western economies into a recession from which they have only recently started to recover. However, the 1987 stock exchange crashes have shown just how fragile that recovery is. ${ }^{96)}$ 97) 98)

The economies of the USA and most European nations, now teetering on the brink of another re- cession, ${ }^{99}$ 100) do not at first glance appear as dependent on imported oil as they were in 1973. Indeed, the reduction of their industrial and consumer oil needs, ${ }^{101)}$ something which the USSR appears unable to emulate, ${ }^{102)}$ resulted in a drop in the demand for imported oil, ${ }^{103)}$ a corresponding drop in oil prices ${ }^{104)}$ and the resulting "oil glut", caused by some countries, desperate for revenues, being forced to expand oil production. ${ }^{105)}$

However, in spite of the present "oil glut", many Western economies are now dependent on cheap oil to hold down inflationary pressures ${ }^{106)}$ and maintain increasingly slender prospects for economic growth. ${ }^{107)}$ 


\section{TABLE 1}

Percentages of total crude oil imported (by nations listed below) from principal oil-exporting Persian Gulf States (Saudi-Arabia, Iran, Iraq, Kuwait and the United Arab Emirates) ${ }^{108)}$

\begin{tabular}{llc}
\hline Nation & 1984 Imports (\%) & 1985 Imports (\%) \\
\hline Japan & 57,76 & 53,97 \\
United States & 13,43 & 7,63 \\
France (including & & \\
Monaco) & 27,42 & 23,33 \\
Germany, Fed. Rep 15,43 & 9,55 \\
Italy and San & & \\
Marino & 33,82 & 26,18 \\
The Netherlands & 33,17 & 26,81 \\
Spain & 39,63 & 27,16 \\
Brazil & 53,84 & 45,32 \\
United Kingdom & 20,58 & 17,14 \\
Belgium & 19,90 & 16,62 \\
Greece & 38,38 & 56,50 \\
\hline
\end{tabular}

(Percentages calculated from 1985 Energy Statistics Yearbook, United Nations, New York 1987, pp 158-161).

Table 1 shows that, while oil imports by the world's leading oil importers from the Persian Gulf States, for the most part, show a declining trend, a sizable portion (105), approximately $15 \%$ of their total oil consumption, still comes from the Persian Gulf. ${ }^{109}$ Indeed, the Pentagon is more dependent on oil from the Persian Gulf than is the USA: $17 \%$ of the US Navy's JP-5 aircraft jet fuel and $12 \%$ of its F-76 diesel marine fuel comes from Gulf States. ${ }^{110}$

While some commentators consider that oil from the Persian Gulf is now comparatively unimportant in the "oil-glut" era, the presence of warships from several Western navies in the Persian Gulf appears to indicate otherwise.

It is not only Western nations whose economies became dependent on oil. The Soviet Union suffered a trade deficit in 1986 in trading with industrialized Western nations largely because of the fall in oil prices. ${ }^{111,}{ }^{112}$ While the USSR exports large amounts of natural gas, oil remains an important source of foreign currency. ${ }^{113,114}$

Indeed, one wonders how much of the current malaise of the Soviet Union (and thus Eastern Europe, dependent on the Soviet economy) is caused by the increasing cost of exploiting the admittedly vast Siberian oil and gas fields ${ }^{115}$ in the face of declining world oil prices which have dropped from $\$ 30$ per barrel to $\$ 14 .{ }^{116}$ In other words, the unanswered question remains: how much of the oil, exported by the USSR to gain foreign currency and also sent to Eastern
Europe to subsidize the communist economies there, is possibly being produced at a loss? Siberian oil is estimated to cost over fifty times more to extract than Saudi Arabian oil, transportation costs excluded. ${ }^{117}$

There are two schools of thought regarding the importance of oil from the Persian Gulf. One, advanced by Shemuel Meir of the Jaffee Center for Strategic Studies, Tel Aviv University, predicts that the present "oil glut" will continue into the 1990's and that oil from the Gulf States will become increasingly unimportant. ${ }^{118}$ As one example, Meir contrasts the minimal effect the threatened closing of the Straits of Hormuz in mid-1984 had on world oil prices, compared with the mass panic caused by the 1973 Arab oil embargo. ${ }^{119}$

Anthony $\mathrm{H}$ Cordesman, of Georgetown University takes the opposite view in his recent book on the Iran-Iraq War, stating that the global "energy glut" will not last beyond the early 1990 's ${ }^{120} \mathrm{He}$ maintains that several key countries Algeria, Ecuador, Gabon, Indonesia and Nigeria), are rapidly consuming their reserves, and are unlikely to be major exporters beyond the mid1990 's. ${ }^{121}$

The importance of the Gulf states, which currently hold an estimated $56,7 \%$ of the world's reserves would thus gradually increase until, by 2000 , industrialized nations would again be dependent on Gulf oil. ${ }^{122,123,124}$

Should this scenario materialize, the sea route around the Cape would then gain in importance for, as Admiral Gorshkov has noted, much of the world's oil is carried in supertankers too large to pass through the Suez Canal, and these ships would be compelled to round the Cape, en route to Europe and the Americas. ${ }^{125}$

The Iran-Iraq war, now entering its eighth year, is a wild card that could affect the Persian Gulf and Western oil supplies in many ways. ${ }^{126,127} \mathrm{How}$ ever, it would appear that both Western and Soviet interests would best be served by an eventual peace without victory for either Iran or Iraq. ${ }^{128}$ It would seem that both the USA and the USSR are working together to achieve this aim. ${ }^{129}$

One reason that the war has dragged on for so long is that Iran and Iraq are so closely matched. Iraq has superior air power, while Iran has larger (and more fanatical) reserves of manpower. The 
Iraqi's excell at static defence, while the Iranians continue to mount suicidal human wave assaults. Iraq can openly buy the most modern Soviet and Western arms for its small army, while Iran is finding it increasingly difficult to buy the arms and equipment for its far larger army ${ }^{130}$ up to four middlemen are now apparently needed to conceal Iranian arms purchases. ${ }^{131}$

The fanatical forces of Muslim fundamentalism in Iran are also occasionally the victims of frauds one shipment to Iran of what was thought to be a load of F-5 jet aircraft parts turned out to be dog food. ${ }^{132}$

\section{Conclusion: who controls the sea routes around the Cape?}

If Vasco da Gama were able to repeat his voyage to Calicut today, he would doubtless require Soviet permission to enter many of the harbours that, in his day, were controlled by the Portuguese. He would too, doubtless be struck dumb at the number of oil supertankers and other merchant vessels following the routes he pioneered, and astounded by the Western restraint shown in the Persian Gulf.

But da Gama would surely ask one question that not many would attempt to answer: who now controls the trade monopoly with the East? $\mathrm{He}$ would point to all the Soviet bases he had encountered on the African coast, and then to the supertankers and container vessels, and ask if they belonged to the Soviet Union, for, in his eyes, surely the Soviet naval bases in Conakry (Guinea), Luanda (Angola), with its 8500 ton floating dock and airfield, Nacala and Maputo (Mozambique) ${ }^{133}$ must be there to protect a trade monopoly. True, the Soviet Navy would not have bases at the old Portuguese controlled ports of Kilwa, Mombasa and Malindi, but if da Gama were to venture into the Red Sea, he would be astounded at the Soviet facilities at Socotra Island near Somalia, at Perim Island, at the entrance of the Red Sea, and at the Ethiopian ports of Massawa and Assab, and the Dahlak archipelago. ${ }^{134}$

When told of the formidable Western bases in the Indian Ocean, of Diego Garcia and the Rapid Deployment Force, ${ }^{135}$ he might well scratch his head and say "But we never relied just on island bases. Why don't you use that base at the Cape of Good Hope - that place they call Simonstown?" And then, doubtless, the conversation would begin to become interesting.
Vasco da Gama would be intrigued at the contingency plan by the NATO command (IBERLANT) in Portugal to protect shipping between the tropic of Cancer and Luanda. ${ }^{136} \mathrm{He}$ would be fascinated by the warnings of Captain John Moore, former Deputy Director of British Naval Intelligence ${ }^{137}$ and editor of Jane's Fighting Ships about Simonstown, ${ }^{138}$ and concerned by the implications of the West not being prepared to sell the RSA Lockheed Orion aircraft to conduct maritime patrols. ${ }^{139}$

Despite numerous speeches made on the subject, ${ }^{140,}{ }^{141}$ Western interest in the sea route around the Cape remains conspicuous by its absence. The unresolved question remains: who now will control the sea routes around the Cape, and the flow of trade and oil that goes with it?

*LI C.M. Meyer B.SC. (Hons), HED is a member of the Citizen force.

\section{Bibliography}

1. Gorshkov, S.G. The Sea Power of the State. Pergamon Press, London, $1980, p 230$.

2. Van Tol, R. and Beaver, P. "Naval line-up in the Persian Gulf. Jane's Defence Weekly, Vol 8 No 12, 26 September 1987, pp 671-673.

3. Cordesman, Anthony $H$. The Iran-Iraq War and Western Security 1984-87: Strategic Implications and Policy Options. Jane's, London $1987, \mathrm{p} 14$.

4. Boorstin, Daniel J. The Discoverers. J.M. Dent and Sons Ltd, London, 1984, p 178.

5. Cordesman, Anthony H. op. cit., p 140

6. Boorstin, Daniel J. op. cit., p 178.

7. Cornwell, Richard. "South Africa and Imperial Naval Defence." Militaria 5/4 1975, p 38.

8. Gorshkov, S.G. op. cit., p 66 .

9. Ibid, pp 249-250

10. Rudolph, Herwig. "The Indian Ocean Power Balance". Africa Institute Bulletin, Vol 25 Nos 9 \& 10, p 101.

11. Nixon, Richard. The Real War, Sidgwick and Jackson Ltd, London, 1980, p 86 .

12. Walker, Martin. The Waking Giant, Abacus, London, 1986, pp $111-112$.

13. "Chernavin - the new C-in-C of the Soviet Navy." Jane's Defence Weekly, Vol 5 No 2, 18 January 1986, pp 61-62.

14. "Changes in the Soviet Military High Command". Jane's Defence Weekly, Vol 6 No 16, 25 October 1986, pp 956-957, p 961.

15. Boorstin, Daniel J. op. cit. pp 173-174.

16. Ibid, p 175.

17. Gorshkov, S.G. op. cit., p 63.

18. Boxer, C.R. The Portuguese Seaborne Empire 1415-1825. Hutchinson, London, 1969, p 39.

19. Boorstin, Daniel J. op. cit, p 174.

20. Boxer, C.R. op. cit, p 28.

21 Axelson, Eric. South-East Africa 1488-1530. Longmans, London, p 34.

22. Ibid, p 14, p 33

23. Boorstin, Daniel J. op. cit., p 177.

24. Cornwell, Richard, op. cit., p 32.

25. Boorstin, Daniel J. op. cit, p 177.

26. Ibid, p 177

27. Cornwell, Richard. op. cit., pp 30-31.

28. "The Voyage of Dias and its Aftermath", Lantern, Vol 37 No 1, January 1988, pp 30-31.

29. Boorstin, Daniel J. op. cit., p 178.

30. Ibid, p 178.

31. Van Schoor, Martinus. "The Spell of the Past". Lantern, Vol 37 No 1, January $1988, p 9$

32. Boxer, C.R. op. cit, p 39.

33. Gorshkov, S.G. op. cit., p 60 .

34. Van Schoor, Marthinus. op. cit., p 9 . 
35. Cameron, Trewhella en Spies, H.B. (redakteurs). Nuwe Geskiedenis van Suid-Afrika in Woord en Beeld, Human en Rousseau, Kaapstad en Pretoria, 1986, p 59 .

36. Lacour-Gayet, Robert. A History of South Africa, Cassell, London 1977, p 7.

37. Cornwell, Richard. op. cit., $\mathrm{p} 31$.

38. Ibid., p 32.

39. Ibid., $\mathrm{p} 31$.

40. Ibid., p 32.

41. Gorshkov, S.G. op cit., p 63

42. Lacour-Gayet, Robert. op cit., $p 7$.

43. Cameron, Trewhella en Spies, H.B. op cit., p 59

44. Cornwell, Richard, op cit., p 33.

45. "The Voyage of Dias and its Aftermath". Lantern, Vol 37 No 1, January 1988, pp 30-31.

46. Cornwell, Richard. op cit., pp 33-34.

47. Cameron, Trewhella en Spies, H.B. op cit., pp 58-59.

48. Ibid., p 60 .

49. Cornwell, Richard op cit, pp 33-34.

50. Gorshkov, S.G. op cit., $p 63$.

51. Cameron, Trewhella en Spies, H.B. op cit., p 74.

52. Cornwell, Richard. op cit., $\mathrm{p} 38$.

53. Cameron, Trewhella en Spies H.B. op cit., p 74.

54. Cornwell, Richard. op cit., $p 38$.

55. Ibid, $\mathrm{p} 38$.

56. Ibid, p 38

57. Cameron, Trewhella en Spies, H.B. op cit., pp 76-79.

58. Gorshkov, S.G. op cit, pp 86-93.

59. Rudolph, Herwig. op cit., pp 102-103.

60. Gorshkov, S.G. op cit, $p 89$.

61. Ibid, pp 89-91.

62. Ibid, $\mathrm{p} 90$.

63. Nixon, Richard. op cit., p 170

64. Walker, Martin. op cit., p 111.

65. Gorshkov, S.G. op cit., pp 91-92

66. Walker, Martin., op cit., p 111.

67. "Chernavin - the new C-in-C of the Soviet Navy. Jane's Defence Weekly, Vol 5 No 2, 18 January 1986, pp 61-62.

68. Ibid., pp 61-62

69. "Changes in the Soviet military High Command". Jane's Defence Weekly, Vol 6 No 16, 25 October 1980, pp 956-957, p 961.

70. Hutchinson, Robert, "Gorbachev tightens grip on Soviet High Command". Jane's Defence Weekly, Vol 7 No 23, 13 June 1987, p 1192. p 1194.

71. "'Do not test us", warn Soviets." Jane's Defence Weekly, Vol 8 No 6 . 15 August 1987, p 275

72. Bodansky, Yossef. "The new generation of the Soviet High Command". Jane's Defence Weekly Vol 8 No 17, 31 October 1987, pp 1010-1012.

73. "Kalinin leads Soviet Airborne Forces". Jane's Defence Weekly, Vol 8 No 21, 28 November 1987, p 1257.

74. "New Soviet head of troops named". Jane's Defence Weekly Vol 8 No 24, 19 December 1987, p 1446

75. Walker, Martin op cit, $p 111$.

76. Ibid, $\mathrm{p} 114$

77. Gorbachev, Mikhail S. Toward a Better World, Hutchinson, London, 1987, pp vii-viii.

78. Lieven, Dominic. "Assessing the Gorbachev Revolution", Issues of Conflict in the Contemporary World - Conflict Studies no 200. Institute for the Study of Conflict, London, June 1987, p 12.

79. Walker, Martin. op cit., pp 50-51.

80. Doder, Dusko. Shadows and Whispers: Power Politics Inside the Kremlin from Brezhnev to Gorbachev. Harrap, London, pp 299-300.

81. Bodansky, Yossef. op cit., p 1010

82. Ibid, p 1010.

83. "Changes in the Soviet Military High Command", Jane's Defence Weekly, Vol 6 No 16, op cit., p 957.

84. "Chernavin - the new C-in-C of the Soviet Navy, Jane's Defence Weekly, Vol 5 No 2, op cit., pp 61-62.

85. Bodansky, Yossef. op cit., $p 1010$

86. Hutchinson, Robert op cit., p 1192, p 1194

87. Walker, Martin op cit. 0111

88. 'SA's own future - Russian envoy.' Pretoria News, 9 April 1988, p 3.

89. Bodansky, Yossef. op cit., p 1010.
90. "Kremlin Reforms Defended". International Herald Tribune", February 19 1988, № 32653, p 1.

91. Walker, Martin. op cit., pp 108-109.

92. Brande, Jonathan "IBERLANT to protect sea area to Angola". Jane's Defence Weekly Vol 6 No 14. 11 April 1987, p 687.

93. Gorshkov, S.G. op cit., pp 14-15

94. Meir, Shemuel. Strategic Implications of the New Oil Reality. Jaffee Center for Strategic Studies, Tel Aviv University, Jerusalem, 1986. p 3.

95. Nixon, Richard. op cit, $p 88$

96. "Ups and Downs in the Global Village. Time, Vol 130 No 16, November 9 1987, pp 29-30.

97. "Sluggish at Best", Time, Vol 131 No 1, January 4 1988, pp 40-41.

98. "The Dollar's Yo-Yo Ride", Time. Vol 131 No 3, January 18, 1988, p $4-8$, pp 11-12.

99. "The Dollar's Yo-Yo Ride", Time, Vol 131 No 3, op cit., p 5, p 8

100. "Sluggish at Best", Time, Vol 131 № 1, op cit., pp 40-41.

101. "The Plundering Continues". Possev no 12 (1319), December 1983. 055

102. Ibid, p 55

103. Meir, Shemuel. op cit., pp 11-12.

104. "Annual Oil Market Report 1986." International Energy Agency, OECD, Paris, 1987, p 8.

105. Ibid, $p$ 14, p 33.

106. "Sluggish at Best". Time, Vol 131 No 1, op cit., p 41.

107. Annual Oil Market Report 1986." op cit., pp 22-23.

108. 1985 Energy Statistics Yearbook. United Nations, New York, 1987. p 158-161.

109. Meir, Shemuel. op cit., p 48.

110. "USN relies heavily on Gulf for fuel". Jane's Defence Weekly, Vol 8 No 7. 22 August 1987, p 295

111. "Soviet Trade Drops in Value". Soviet Analyst, Vol 16 No 13, July 1987, p 4.

112. "What Perestroika means for American business". Science, Vol 239 No 4 844, 4 March 1988, p 1088.

113. "Soviet Trade Drops in Values p 4.

114. "The Plundering Continues". Possev no 12 (1319), December 1983, p 55.

115. Ibid, pp 54-55.

116. Walker, Martin. op cit., pp 50-51, p 73, pp 80-81, pp 82-83.

117. "The Soviet Empire: Pressures and Strains". ISC Special Report, London, January 1980, p 27.

118. Meir, Shemuel. op cit., p 5.

119. Meir, Shemuel. op cit, p 81.

120. Cordesman, Anthony H. op cit., p 12.

121. Ibid, $\mathrm{p} 13$.

122. Ibid, pp 12-15.

123. Cordesman, Anthony. "Iran-Iraq war and the West". Jane's Defence Weekly, Vol 8 No 6, 15 August 1987, po 281-282.

124. "Annual Oil Market Report 1986". op cit., p 1, p 25.

125. "Gorshkov, S.G. op cit., p 12.

126. Cordesman, Anthony, op cit., pp 9-17.

127. Cordesman, Anthony. "Iran-Iraq War and the West". op cit., pp 281-282.

128. Cordesman, Anthony. op cit., pp 144-162.

129. "The USSR and the Persian Gulf". Possev no 9 (1364), September 1987, pp $17-18$.

130. Cordesman, Anthony. op cit., pp 18-60.

131. Ibid., p 33

132. Ibid., p 28.

133. Jane's Fighting Ships 1985-86. Jane's Publishing Company Ltd. London 1985, p 139.

134. Rudolph, Herwig. op cit., p 102.

135. Ibid., pp 102-106.

136. Braude, Jonathan op cit. 0687.

137. Rees, David. Soviet Sea Power: The Covert Support Fleet. Conflict Studies, no 84. June 1977. Institute for the Study of Conflict. London, p 2 .

138. Jane's Fighting Ships 1987-88. Jane's Publishing Company Ltd, London 1987, p 123.

139. "Cape defence low priority, says Malan". Jane's Defence Weekly, Vol 8 No 23, 12 December 1987, p 1350.

140. Speech by the State President on the acceptance into use of the SAS Drakensberg, Cape Town Harbour. 11 November 1987.

141. Speech by the Mayor of Cape Town at the Navy League AGM, Cape Town, 13 June 1987. 